\title{
A Cidade \& A Cidade, de China Miéville: uma crítica contemporânea ao imperialismo
}

\author{
Gabriel Zupiroli de Almeida*, Carlos Eduardo Ornelas Berriel.
}

\section{Resumo}

Este trabalho busca elaborar uma investigação acerca do romance "A Cidade \& A Cidade" (2009), do autor inglês China Miéville, e relacionar seus aspectos distópicos com a crítica presente no texto a formas contemporâneas de imperialismo e, consequentemente, de problemas sócio-urbanos interligados diretamente com a concepção de "fronteiras" visíveis e invisíveis - estas que se colocam como produto direto das relações históricas de classe e podem ser evidenciadas no romance através de sua construção distópica e política.

\section{Palavras-chave:}

distopia, ficção científica, pós-modernidade.

\section{Introdução}

A obra de China Miéville é marcada pela utilização do gênero literário do new weird, um desmembramento da ficção científica surgido nos anos 90, que incorpora elementos fantásticos e contemporâneos à escrita.

Como afirma Carl Freedman 1 , em seu romance $A$ Cidade \& A Cidade (2009), o autor realiza um afastamento de tal gênero e se desdobra sobre o romance policial para pautar elementos críticos às configurações contemporâneas do imperialismo em países de "terceiro mundo" e, consequentemente, aos problemas urbanos.

Dessa maneira, é possível notar como se articulam e dialogam os elementos distópicos presentes no texto com a crítica sociopolític, tendo em vista de que o gênero literário serve está totalmente atrelado ao conteúdo expresso pela narrativa.

\section{Resultados e Discussão}

Para tais investigações, foi decidido abordar o romance através de três linhas investigativas que pudessem, cada uma à sua forma, contribuir para o resultado final como uma síntese da crítica política do livro. Essas três vertentes foram: um breve estudo sobre a classificação do romance dentro do gênero new weird; uma análise da presença dos aspectos distópicos que legitimam o viés político da obra; e, por fim, o estudo em si do pensamento urbanista relacionado às fronteiras e à situação classista que as legitimam.

$\mathrm{Na}$ primeira vertente, foi possível estabelecer algumas noções do gênero new weird através do estudo de duas opiniões diferentes: a de Freedman, que alega que o autor se afasta do gênero em seu romance, e a de Eliska Fialová, que defende a existência do new weird dentro das características literárias que compõem o livro. O estudo do gênero se mostrou importante para a compreensão da crítica, já que uma das principais características do mesmo é, justamente, a presença de uma crítica política essencialmente contemporânea.

Através da investigação dos elementos distópicos, partindo principalmente de artigos de Darko Suvin, foi possível notar a presença do gênero no romance de China, principalmente no que remete à construção de uma entidade opressiva - a Brecha. Por mais que não se trate, ao todo, de uma distopia, os aspectos distópicos estão substancialmente embutidos na narrativa e se encontram diretamente relacionados com a crítica política no passo que o gênero historicamente surge e se baseia em pensamentos políticos diversos. A distopia não deixa de ser, sobretudo, um gênero que comporta um ideal de sociedade, ainda que negativo, que busca esboçar tanto uma crítica a um sistema vigente, quanto um alerta a um possível futuro.

Por último, e relacionando com os outros dois pontos estudados, analisou-se a presença do pensamento político embutido no romance. A princípio, partiu-se do conceito trotskista de "desenvolvimento desigual e combinado" para analisar a presença de um imperialismo moderno como alvo de crítica da obra. Porém, durante o desenvolvimento da pesquisa, foi observada a necessidade de estudar também material sociológico e filosófico que aborda a questão urbana e das fronteiras sociais. Para isso, autores como Henri Lefebvre foram lidos e foi possível notar - como afirma o próprio Miéville em entrevistas - que a crítica política é produto de, e está diretamente atrelada às noções de fronteiras invisíveis das cidades, produtos de um subdesenvolvimento colonial e imperialista.

\section{Conclusões}

Dessa forma, conclui-se que a crítica aos problemas sociológicos urbanos está fortemente presente no romance sob o aspecto de fronteiras, ligado de maneira direta às questões de gênero literário que agregam o romance, criando, assim, uma conexão evidente entre a distopia, o new weird e o pensamento marxista da obra.

\section{Agradecimentos}

Agradecemos à instituição UNICAMP por nos possibilitar a realização da pesquisa, ao professor Carlos Eduardo $\mathrm{O}$. Berriel pela orientação vigente e à instituição de fomento que possibilitou a continuidade do trabalho, Conselho Nacional de Desenvolvimento Científico e Tecnológico (CNPq) e ao Programa Institucional de Bolsas de Iniciação Científica (PIBIC).

${ }^{1}$ FREEDMAN, Carl. From Genre to Political Economy: Miéville's The City \& The City and Uneven Development. CR: The Centennial Review, Michigan State University Pres, v. 13, No. 2, p. 13-30, Fall 2013. 